УДК 911.332

\title{
АНАЛІЗ ТА ОЦІНКА ЗЕЛЕНОГО ТУРИЗМУ ЯК ЕЛЕМЕНТУ ПІДПРИЕМСТВА В ЗАКАРПАТСЬКІЙ ОБЛАСТІ
}

\section{ANALYSIS AND EVALUATION OF GREEN TOURISM AS AN ELEMENT OF ENTERPRISE IN THE TRANSCARPATHIAN REGION}

\author{
Машіка Ганна Василівна \\ доктор географрічних наук, професор, \\ ДВНЗ «Ужгородський національний університет» \\ ORCID: https://orcid.org/0000-0001-6063-5823 \\ Пригара Ольга Василівна \\ кандидат біологічних наук, доцент, \\ ДВН3 «Ужгородський національний університет» \\ ORCID: https://orcid.org/0000-0003-3433-7173 \\ Mashika Hanna, Pryhara Olha \\ Uzhorod National University
}

\begin{abstract}
У науковій статті досліджено особливості розвитку зеленого туризму, проведено його аналіз та здійснено оцінку як елементу підприємництва в Закарпатській області, адже туризм виступає важливою складовою кожної країни, оскільки суб'єкти туристичного сектора тісно співпрацюють з іншими галузями, забезпечуючи залучення інвестиційних ресурсів, зміцнюючи дохідну частину бюджету, покращуючи платіжний баланс країни, а також сприяє стійкому економічному зростанню та підвищенню добробуту населення .У багатьох селах Закарпатської області нині спостерігається зменшення населення, зростає масова заробітчанська міграція. Розвиток зеленого туризму позитивно впливатиме на сумну тенденцію безробіття в українських селах, може підвищити матеріальний добробут та частково вирішити проблеми зайнятості сільського населення. У статті проаналізовано та систематизовано лімітуючі та генеруючі фрактори розвитку зеленого туризму в області, розроблено туристичне районування зеленого туризму з метою виділення пріоритетних туристичних зон для його розвитку. Окреслено основні напрями покращення для подальшого моніторингу перспектив розвитку зеленого туризму в області.
\end{abstract}

Ключові слова: зелений туризм, туристична галузь, сільські території, туристичне районування, туристичні зони, підприємництво, Закарпатська область.

В научной статье исследованы особенности развития зеленого туризма, проведен его анализ и проведена оценка как элемента предпринимательства в Закарпатской области, ведь туризм выступает важной составляющей каждой страны, поскольку субъекты туристического сектора тесно сотрудничают с другими отраслями, обеспечивая привлечение инвестиционных ресурсов, укрепляя доходную часть. бюджета, улучшая платежный баланс страны, а также способствует устойчивому экономическому росту и повышению благосостояния населения. Во многих селах Закарпатской области в настоящее время наблюдается уменьшение населения, растет массовая миграция. Развитие зеленого туризма положительно повлияет на печальную тенденцию безработицы в украинских селах, может повысить материальное благосостояние и частично решить проблемы занятости сельского населения. В статье проанализированы и систематизированы лимитирующие и генерирующие фракторы развития зеленого туризма в области, разработано туристическое районирование зеленого туризма с целью выделения приоритетных туристических зон для его развития. Намечены основные направления улучшения для дальнейшего мониторинга перспектив развития зеленого туризма в области.

Ключевые слова: зеленый туризм, туристическая отрасль, сельские территории, туристическое районирование, туристические зоны, предпринимательство, Закарпатская область. 
The research article examines the features of green tourism development, analyzes it and evaluates it as an element of entrepreneurship in the Transcarpathian region, because tourism is an important component of each country, as tourism sector works closely with other industries, attracting investment resources, strengthening revenue budget, improving the country's balance of payments, and contributes to sustainable economic growth and welfare. In many villages of the Transcarpathian region, the population is currently declining, and mass labor migration is growing. The development of green tourism will have a positive effect on the sad trend of unemployment in Ukrainian villages, may increase material well-being and partially solve the problems of rural employment. The article analyzes and systematizes the limiting and generating factors of green tourism development in the region, developed tourist zoning of green tourism in order to identify priority tourist areas for its development. It is important for the Transcarpathian region to explore and realize the existing rich tourism potential by implementing a balanced national regulatory policy for small business development, including at the regional level. Today, scientific confirmation of the status and role of green tourism in the socio-economic priority system of regional and local development is also extremely important. The development of green tourism in the rural areas of the Transcarpathian region should be a catalyst for economic restructuring, ensuring the stability of the population and solving pressing social and economic problems in rural areas. The purpose of the scientific article is to study the peculiarities of the development of green tourism, to provide an analytical assessment of its planning aspects and organization as an element of entrepreneurship in the Transcarpathian region. The article outlines the main areas of improvement for further monitoring of the prospects for green tourism in the region. Research has concluded that green tourism can be seen as an integral part of the comprehensive social and economic development of rural areas and as a means of addressing the rural population, especially employment through tourism enterprises. As an element of the enterprise, green tourism plays a significant role not only in the development of territorial communities in rural areas but in the development of the region as a whole.

Keywords: green tourism, tourist branch, rural territories, tourist zoning, tourist zones, business, Transcarpathian region.

Постановка проблеми. Сучасний стан української туристичної галузі вимагає посилених процесів для створення в нашій країні потужної туристичної галузі, яка може задовольнити потреби жителів України та іноземних туристів. Слід мати на увазі, що організація підприємницької діяльності $€$ головним чином економічним та соціальним завданням, і сьогодні ця проблема повинна бути вирішена на національному та регіональному рівнях. На даному етапі розвитку Закарпатська область набуває ефективної структури управління туризмом на всіх рівнях, питання децентралізації та концентрації, а також чітке визначення влади на кожному рівні стають все більш важливими. У цьому контексті людей дуже турбує стан зеленого туризму та перспективи розвитку підприємств малого та середнього бізнесу в даній сорері на цьому етапі. При правильній організації ресурсний потенціал зеленого туризму необмежений. 3 огляду на це, дослідження розвитку зеленого туризму $є$ дуже перспективними. Розвиток зеленого туризму в сільських територіях Закарпатської області повинен стати каталізатором економічної перебудови, забезпечення стабільності населення та вирішення нагальних соціальних та економічних проблем у сільській місцевості. Для Закарпатської області важливо досліджувати та реалізувати наявний багатий туристичний потенціал шляхом впровадження збалансованої національної регуляторної політики для розвитку малого бізнесу, в тому числі на регіональному рівні. Сьогодні наукове підтвердження статусу та ролі зеленого туризму в соціально-економічній пріоритетній системі регіонального та місцевого розвитку також $€$ надзвичайно важливим.

Аналіз останніх досліджень і публікацій. Значний внесок у дослідження проблеми розвитку сільського зеленого туризму зробили вітчизняні вчені А. Ю. Алієва, О. М. Бородіна, Б. В. Буркинський, 3. В. Герасимчук, Г. О. Горіна, Л. С. Гринів, П. В. Ґудзь, л. П. Дядечко, Г. В. Машіка, О. І. Мілашовська, С. Г. Нездоймінова, Т. І. Ткаченко, М. А. Хвесик, Є. В. Хлобистова, В.І.Цибух, Л. М. Чепурда та інші. Широке коло питань проблематики зеленого туризму досліджують зарубіжні вчені: К. Дронг, В. Котлінський, Я. Маєвський, С. Медлік, Я. Сікора та ін. Віддаючи належне науковим доробкам наведених авторів необхідно відзначити, що комплексне дослідження проблеми стимулювання і підтримки розвитку зеленого туризму нині відсутнє. Враховуючи сучасний стан розвитку зеленого туризму важливу роль відіграє його аналіз та оцінка як елементу підприємництва, що робить досліджувану тематику актуальною, оскільки сфера послуг має велике значення для соціально-економічного розвитку Закарпатської області.

Виділення невирішених раніше частин загальної проблеми. Як фрорма підприємницької діяльності розвиток зеленого туризму включає безліч причин, які повинні сприяти подальшому розвитку та забезпечувати належний рівень конкуренції, що особливо важливо в ринкових умовах. Акцентуючи увагу на його розвиток, доцільно провести 
його аналіз та оцінку з врахуванням елементів підприємництва в Закарпатській області.

Формулювання цілей статті (постановка завдання). Метою наукової статті $€$ дослідження особливостей розвитку зеленого туризму ,надання аналітичної оцінки його планувальних аспектів та організації як елементу підприємництва в Закарпатській області.

Виклад основного матеріалу дослідження. Розвиток зеленого туризму є життєво важливим для всього Карпатського регіону. Привабливість цього виду туризму полягає в тому, що він є більш доступним. Для срермерів це також вигідно: вони можуть із задоволенням приймати туристів, пропонувати їм проживання та надавати різні послуги, поки вони платять. В даному регіоні $€$ всі можливості щоб займатися зеленим туризмом протягом року. Близько $80 \%$ його території $є$ частиною Карпат. Найкрасивіші ділянки середньої висоти в Карпатах: Верховинський хребет, Чорногора, Горгани, Свидовець, Полонинський хребет, Рахівський хребет, Карпатський хребет відокремлює їх від решти території України, що дало змогу століттями зберігати традиційну культуру та надати цій території неповторного колориту. На сьогодні 94\% населених пунктів області $\epsilon$ сільськими поселеннями, і там проживає $71 \%$ населення. В області існує близько 600 різних туристичних маршрутів для забезпечення розвитку зеленого туризму, з яких близько 400 мають сертифрікат. Карпати знову стають популярними в країні та за кордоном. В результаті організації молодіжних і сімейних турів (спортивний, екотуризм, пригодницький, релігійний, конореренц-туризм, пізнавальний, тематичний, індивідуальний і інші) почали стрімко розвиватися на в Закарпатті.

Для проживання екотуристи вже можуть використовувати туристичні комплекси, а також приватне житло, участь фракторів природного оздоровлення, захоплюючих форм рельєфу, привабливих історичних будівель сприяють подальшому розвитку даного виду діяльності. Закарпаття має дешеву, ефективну та доступну туристичну інфрраструктуру для сільського туризму. Для кращої оцінки розвитку зеленого туризму у сільській місцевості ми можемо зосередитись на стратегію регіонального розвитку Карпатського регіону на період 2021-2027 років [7]. Дана програма дає нам більш актуальні данні, які в свою чергу діють нас змогу спостерігати детальніший розвиток регіону та його сільських територій в майбутньому. Зелений туризм вважається однією з провідних галузей, яка може позитивно вплинути на розвиток всієї області.
У сільській місцевості проживає 62,9\% населення Закарпатської області. Якщо сільські райони використовувати раціонально, природний, демограсрічний, економічний, історичний та культурний потенціал $€$ величезним, що може зробити вагомий внесок у вирішення соціально-економічного розвитку району та підвищенню туристичної привабливості в цілому [1]. Однак більшість сучасних сільських поселень перебувають у стані економічної нестабільності, що призвело до скорочення населення, трудової міграції, колапсу соціальних закладів та все ще високого рівня бідності в селах. Важливим питанням у сільській місцевості $є$ сировинна орієнтація економіки, тому абсолютна більшість сільського населення не бере участі у розподілі доходу від їх використання. В Закарпатській області потрібно розробити концепцію сталого розвитку в сільській місцевості, завданням якої $€$ з'ясування та аналіз ключових питань розвитку зеленого туризму та сільських територій, а також використання соціально-економічних та управлінських важелів для досягнення нового рівня якості розвитку сільських територій. Можна вважати, що ця концепція сприятиме реалізації цієї мети шляхом переходу від галузевого підходу, який поступово фрормується сьогодні, до територіального управління розвитком сільських територій. Це означає, що інші елементи сільського способу життя: виробнича та соціальна інфрраструктура, медицина, освіта, побутове обслуговування населення, системою комунікації, розвитком несільськогосподарських видів діяльності. Перехід від галузевого розвитку до просторового є основним способом переходу від одногалузевої структури сільської економіки до багатофуннціонального розвитку сільських територій, забезпечення продуктивної зайнятості та розширення джерела доходу сільського населення в умовах ринкового переходу. Багатофрункціональним інструментом розвитку $є$ диверсисрікація та модернізація сільської економіки, що прискорить структурні зміни та відкриє простір сільського середовища для реалізації зростаючих несільськогосподарських цілей, розширять сореру прикладання інтелектуальної висококваліфрікованої праці як головної умови закріплення молоді на селі. Проблема в Закарпатській області $€$ основним незбалансованим фрактором соціально-економічного розвитку низовин та гірських районів регіону. Більшу частину території займають гори, а третина населених пунктів отримали статус гірських. 
Значні відмінності в показниках Закарпатського регіону спричинені неоднорідністю енергетичного, трудового та інфрраструктурного потенціалу. Регіональні ресурси зосереджені переважно в низинах. Область вживає заходів щодо створення та розширення існуючих об'єктів Фонду охорони природи, на цій території слід охороняти, зберігати та відновлювати природні заповідники та об'єкти із особливими природоохоронними, науковими, естетичними та рекреаційними цінностями.

Перспективною галуззю регіону є зелений туризм, тому залучення іноземних інвестицій може зробити регіон потужною зоною для міжнародного туризму. Унікальне геополітичне розташування на перетині міжнародних транспортних, економічних, торгових та культурних шляхів допомагає розвиватись та поглиблювати всебічну співпрацю між країнами та відіграє важливу роль в інтеграції України в європейську структуру [4]. Переваги географрічного розташування (кордони, транспорт) регіону, а також природні особливості та трудовий потенціал слід використовувати для діалогу щодо реалізації інвестиційних проектів у регіоні. Впроваджувати транскордонні інфрраструктурні проекти для збільшення його економічного потенціалу та добробуту населення. В межах туристичних зон найшвидше розвивався сільський зелений туризм завдяки садибам у Берегівській-42, Хустській-31, Ужгородській-19 та Мукачівській-23.

Найкраще зелений туризм розвивається в традиційних туристичних районах наступних регіонів: Рахівський (смт Ясіня, с. Кваси), Ужгородський (с. Вишка, с. Ужок), Хустський (с. Пилипець), Мукачівський та Берегівський. Близько 600 господарств в цих районах періодично приймають відпочиваючих у своїх оселях. У сільській місцевості Закарпатської області є багато цікавих пам'яток, пов'язаних 3 народними ремеслами: ткацтво, вишивка, гончарне мистецтво, лозоплетіння, різьба по дереву, розкриваючи походження та походження народної культури. Серед них $є$ дуже унікальні, чи не єдині в Європі музеї, такі як Музей кузні «Кузня Гамора» в селі Лисичево та Музей лісу і сплаву на річці Чорна. Це забезпечує широкі можливості для гостей заміської садиби розробляти та реалізовувати цікаві плани. Переваги зеленого туризму в селах оцінили громадяни сусідніх прикордонних країн. Особливо на Берегівщині близько 200 сімей надають послуги такого типу. Усі

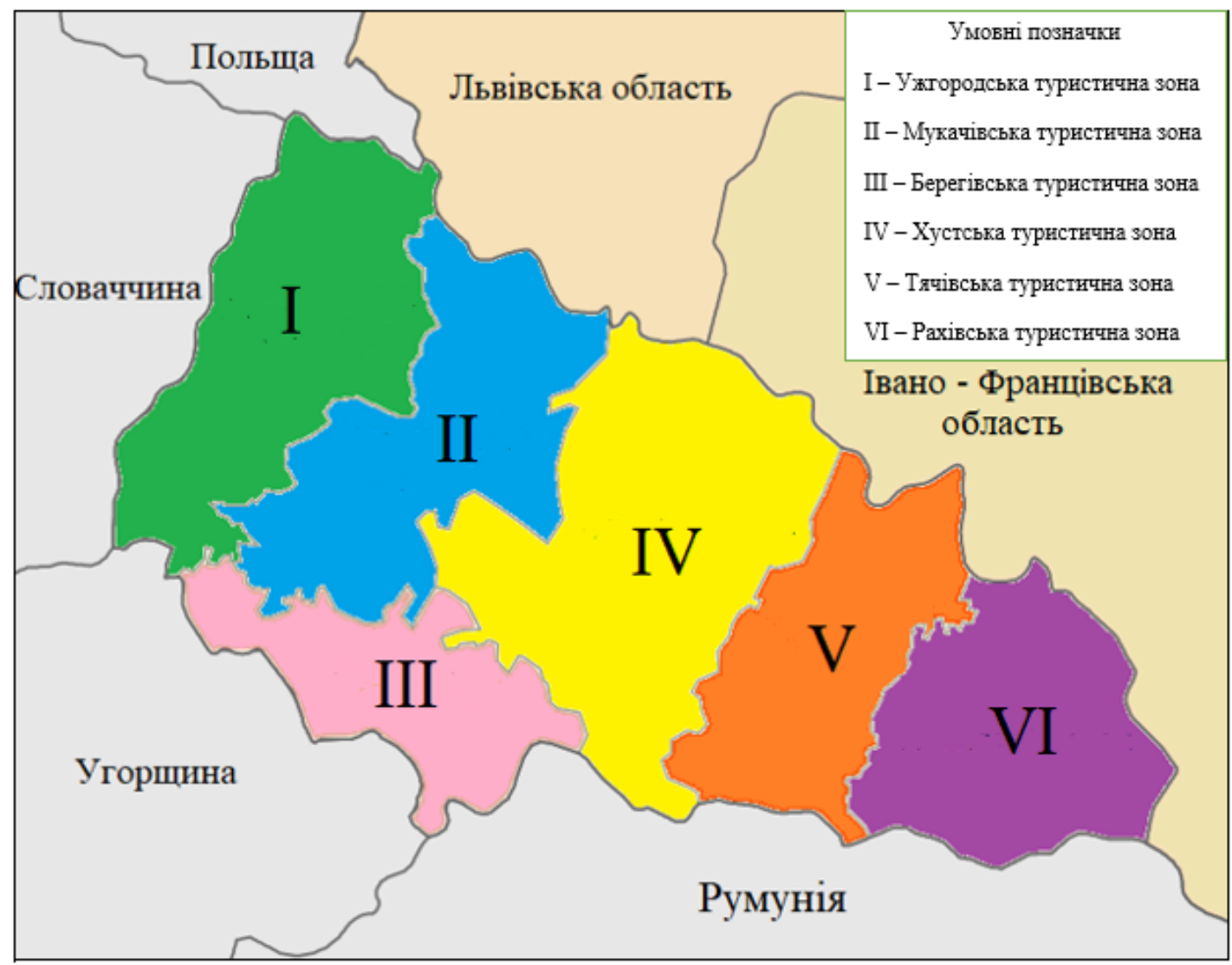

Рис. 1. Туристичне районування зеленого туризму Закарпатської області Джерело: побудовано авторами за даними [7] 
вони пройшли спеціальну підготовку та мають сертисрікати [3].

Для подальшого моніторингу перспектив розвитку зеленого туризму на Закарпатті доцільно буде зробити детальний аналіз туристичних ресурсів кожну зону окремо.

Ужгородська туристична зона. Ужгородська туристична зона розташована у західній частині регіону, межує з Угорщиною, Словаччиною та Польщею. Завдяки чудовому геополітичному положенню регіону розвивається туризм та відпочинок, а туристи з усіх регіонів України та інших країн залучаються для оздоровлення та відпочинку. Територія вражає вишуканою естетикою гірських ландшастів, лісистих гір, квітучих пасовищ, швидкоплинних річок та відновлення джерел мінеральної води. Основні мінеральні ресурси зони представлені чотирма різними типами родовищ мінеральної води-Арзні (вуглеводнево-вуглекислий хлорид, натрій): Костринське, Солянське, Хоронхоловське-Пастильківське та келечинського типу: Ужоцьке та Чорноголівське-Пастильківське. Крім того на території у занходиться Ужанський національний природний парк що займає понад 48\% загальної площі області (39159 га). Район є одним з найчистіших куточків України. Данна зона є одним з найчистіших куточків України. Гора Красія (1036 м н.р.м.) $\epsilon$ однією з найвищих вершин у регіоні і $€$ найбільшим гірськолижним курортом 3 відповідною інорраструктурою [2].

Мукачівська туристична зона. Мукачівська туристична зона - один із найбільш захоплюючих регіонів Карпат, розташований у західній частині області. Він займає найбільш вигідне становище серед усіх регіонів регіону. У минулому існували давні торгові шляхи, які в історичних документах називали "Великими слов'янськими шляхами". Сьогодні міжнародна важлива магістраль Київ - Ужгород перетворена на п'ятий транс'європейський коридор міжнародного значення на трасі Трієст - Львів. Через цей район проходить Міжнародна залізнична лінія Пулау. Вони пов'язують Україну із Західною Європою. Туристична зона славиться своєю матеріально - рекреаційною базою. Цьому можуть сприяти всі природні фрактори, найголовніший 3 яких цілюща мінеральна вода. Наявність мікроелементів у мінеральній воді дає всі права на їх класифрікацію, які $є$ високоефективними та цінними при лікуванні та профрілактиці різних захворювань внутрішніх органів людини. Територія багата на гірські масиви у північній частині. Гірські хребти простягаються 3 північного заходу на південний схід, у цьому напрямі збільшується їхня висота, змінюється вигляд. Окрасою і багатством району є рослинний і тваринний світ, що відзначається різноманітним видовим складом [7].

Берегівська туристична зона. Пріоритетним напрямком туризму в Берегівській зоні також вважається сільський туризм, з надією в селах, Бене, Боржава, Дейда, Велика Бахта та інших населених пунктах. Екскурсійний маршрут дозволяє гостям дізнатись про історію, пам'ятники угорської культурні традиції даної місцевості. Район має середньовічні замки у палацах родини Віфлеєм Квасово, Варієво та Берегове. Окреслена територія відома гостинністю власників заміських садиб. Запаси гарячої води Карпат у Берегівській туристичній зоні в основному поділяються на три типи: вуглекислі, кремнієві гарячі води (Берегівське родовище), азотні води (Іванівське, Боржавське родовище) та азото-метані води, йодисто бромні (Гараздовське родовище). 3 метою ефрективного розвитку сільського зеленого туризму створено всі необхідні умови: природні та кліматичні характеристики; відновлено роботу гарячої води та її природи; унікальні туристичні визначні пам'ятки: національно важливий квітковий заповідник "Чорна гора", чудова Будинок замку (замок "Канків", "Замок Ньолаб" у селі Королеве, Місцевий музей легенд (Виноградівський музей місцевих легенд, Етнографрічний музей села Новоселиця, Місцевий музей легенд Затисянського в селі Тисобикен (вгорі), Художній музей у селі Пійтерфолво (Петрово), архітектурні пам'ятки (Вознесенська церква-XIV століття, Успенська церква та дзвіниця XVII століття в СантаМарія-Новелла, фрранцисканські монастирі та церкви, палац Перені у Віно-Радіффрі та ін.). Розвиток створеного фрундаменту зеленого туризму є дуже важливим для цього регіону. Основна увага приділяється розвитку елітного туризму - мисливства, риболовлі, верхової їзди, їзди на велосипеді, екології та етнографрії - переважно в місцях проживання етнічних меншин (угорців) [5].

Хустська туристична зона. Хустська туристична зона славиться своїми унікальними пам'ятками природи. 3 часів Льодовикового періоду в районі Кіреші збереглися низинні вузьколисті нарциси. Це єдине диво в Європі, яке приваблює туристів з різних регіонів України та 3-за кордону. Це також єдине місце 3 унікальною популяцією карпатських буйволів із відновленим молоком із 9\% жиру. Хустська земля довгий час була носієм пра- 
вославної церкви Закарпаття, тому сьогодні вона $€$ центром багатьох монастирів. Кам'яні культові споруди збереглися в селі Вишкові (ресрорматорська церква в 1270 р.) Та в Хусті (церква Єлизавети 3 кінця XIII ст.). Туристична зона розташована біля підніжжя мальовничої гори в долині Боржава, де безліч річок і струмків протікає передгір'ями. В районі Іршави це одне 3 найбільших родовищ гарячого метану типу Хайдусобосло, хлоридів вуглеводнів, натрію та йодистого метилу. Багато 3 цих джерел знаходиться в сільській місцевості: Велика Розтока, Мала Розтока, Кам'янське, Мідяниця, Дунковиця, Драгобрат та ін. Родовище приєднане до вугленосних порід Ільницького вугільного родовища. Іршавське родовище в Україні не має прямого аналога гарячої води 3 вмістом метану, йоду та бромом етану. Важливою туристичною визначною пам'яткою Закарпаття $€$ Боржавська вузькоколійка, яка була побудована з 1907 по 1909 рік, а її довжина досягла 107 кілометрів у 1926 році. За радянських часів рух тут повністю зупинився. В останні роки реставрація проводилась у таких частинах: Іршава-Хмільник, Хмільник-Виноградів. Ділянка Хмільник-Берегове використовується для технічного машинобудування. Хоча за останні 20 років залізнична лінія не відремонтована, 80\% шпал потрібно негайно замінити, а локомотиви двох з половиною століть на шість вагонів потребують термінового ремонту об'єкт щороку приваблює тисячі людей з Великобританії, Австрії та Чехії [6].

Тячівська туристична зона. Територія туристичної зони розташована на південному сході Закарпаття - найбільша територіальна одиниця (площа області становить 14\% від області). На території області знаходиться 62 населених пункти, 19 з яких мають статус гірських поселень. У цій місцевості знайдено понад 67 видів мінеральної води (включаючи гарячу), яка містить до 20 мікроелементів, які мають важливе значення для здоров'я людини, і їх ефективність не менша, ніж відомі води Кавказу, Чехії та Франції. Основним напрямком ефрективного розвитку туризму та відпочинку в регіоні $€$ використання соляних шахт для лікування органів дихання та багатьох супутніх захворювань [2].

Рахівська туристична зона. Рахівщина лідеру впровадженні зеленого туризму в Україні. У 1995 р. Рада директорів Фонду розвитку Єврозони Карпат (м. Кошице, Словаччина) затвердила проект "Створення передумов для екологічно орієнтованого сталого розвитку гірських поселень у Рахівській туристичній зоні Закарпаття". Візитною карткою Рахівщини $є$ досвід громади с. Кваси. У 2000 році Кваси виграли нагороду за найкращий досвід в інноваційній діяльності органів місцевого самоврядування в Єврозоні Карпат. Квасівська сільська громада співпрацювала 3 громадською організацією - Агентством регіонального розвитку Карпат - запропонувати інноваційний проект на тему: "Відродження гуцульської традиції в громаді. Квас - як передумова комплексного розвитку гірських сіл". Сьогодні на Рахівщині головним населеним пунктом для розвитку зеленого туризму $\epsilon$ селище міського типу Ясіня. Близько 150 фермерів Ясіня надають послуги гостинності.

Висновки. Отже, розвиток зеленого туризму на пряму залежить від географрічного розташування регіону та наявності певних туристичних ресурсів. Важливою особливістю розвитку туризму в регіоні $€$ те, що глобалізація туристичної інфрраструктури стимулювала появу нових сільських будинків, що надають різноманітні туристичні послуги. Стан розвитку підприємницької діяльності в галузі зеленого туризму в області має досить хороші перспективи. Закарпатська область $€$ ініціативним регіоном нашої держави в плані розвитку зеленого туризму, але $є$ низка лімітуючих чинників, які гальмують його розвиток. Основними проблемами в управлінні національними туристичними підприємствами $€$ : низькі інвестиції в розвиток туризму та незадовільні умови зменшення кількості працівників, складність залучення висококваліфікованих фрахівців та значний ступінь ризику банкрутства при розробці та впровадженні у виробництво нового виду продукції. Щодо генеруючих чинників, то можна сказати, що розвиток зеленого туризму має досить багато позитивних якостей до яких можна віднести: зацікавленість населення в розвитку даної галузі, наявність великого природно ресурсної бази, відносно вільний сільський житловий фронд для прийому туристів та інші. Дослідження дозволили зробити висновок про те, що зелений туризм можна розглядати як невід'ємну частину всебічного соціального та економічного розвитку сільських територій і як засіб вирішення проблеми сільського населення, особливо зайнятості за допомогою туристичних підприємств. Як елемент підприємства зелений туризм відіграє значну роль не тільки у розвитку територіальних громад сільської місцевості але в розвитку області в цілому. Що позитивно пливатиме на туристичний імідж в цілому і буде приваблювати як вітчизняних так і іноземних туристів. 


\section{СПИСОК ВИКОРИСТАНИХ ДЖЕРЕЛ:}

1. Алієва А.Ю. Організаційно-економічні засади сталого розвитку туристично-рекреаційної сфери в Україні : дис. на здобуття наук. ступ. к. екон. наук : 08.00.03. Волинський національний університет імені Лесі Українки, Луцьк : Національний університет водного господарства та природокористування. Рівне, 2021. 225 с.

2. Биркович В.І. Сільський зелений туризм - пріоритет розвитку туристичної галузі України. Стратегічні пріоритети. Науково-аналітичний щоквартальний збірник. 2011. № 1(6). С. 138-143.

3. Власенко І.В. Стан підприємництва у сфері сільського зеленого туризму в Україні та за кордоном. Науковий вісник Львівського національного університету ветеринарної медицини та біотехнологій. 2017. № 76. С. 26-30.

4. Збарський В.К., Грибова Д.В., Збарська А.В., Оваденко В.І. Малі форми господарювання у розвитку внутрішнього туризму України. Вісн. Черкаського ун-ту. Серія «Економічні науки». 2020. Вип. 2. С. 160-169.

5. Kornieiev M., Horb K., Kurzova M. Development of the Ukrainian Tourism Industry in the Context of Integration to the EU. Східна Європа: економіка, бізнес та управління. 2019. Випуск 2(19). С. 21-26.

6. Колективні засоби розміщування (2011-2020). Державна служба статистики України. URL: http://www.ukrstat.gov.ua/

7. Про схвалення Стратегії розвитку туризму та курортів на період до 2026 року : Розпорядження КМУ від 16.03.2017 p. № 168 p. URL: https://zakon.rada.gov.ua/laws/show/168-2017p

\section{REFERENCES:}

1. Alijeva, A.Ju. (2021) Orghanizacijno-ekonomichni zasady stalogho rozvytku turystychno-rekreacijnoji sfery v Ukrajini: dys. na zdobuttja nauk. stup. k. ekon. nauk 08.00.03. Volynsjkyj nacionaljnyj universytet imeni Lesi Ukrajinky. Lucjk; Nacionaljnyj universytet vodnogho ghospodarstva ta pryrodokorystuvannja. Rivne, 225 p. (in Ukrainian)

2. Byrkovych V.I. (2011) "Green rural tourism - tourism development priority of Ukraine". Stratehichni priorytety. Naukovo-analitychnyj schokvartal'nyj zbirnyk, 1(6), 138-143.

3. Vlasenko I.V. (2017) "The state of entrepreneurship in the field of rural green tourism in Ukraine and abroad". Naukovyj visnyk L'vivs'koho natsional'noho universytetu veterynarnoi medytsyny ta biotekhnolohij, 76, 26-30.

4. Zbars'kyy V.K., Hrybova D.V., Zbars'ka A.V., Ovadenko V.I. (2020) Mali formy hospodaryuvannya u rozvytku vnutrishn'oho turyzmu Ukrayiny [Small forms of management in the development of domestic tourism in Ukraine]. Bulletin of Cherkasy University. Series "Economic Sciences", 2, 160-169.

5. Kornieiev M., Horb K., Kurzova M. (2019) Development of the Ukrainian Tourism Industry in the Context of Integration to the EU [Development of the Ukrainian Tourism Industry in the Context of Integration to the EU]. Skhidna Jevropa: ekonomika, biznes ta upravlinnja - Eastern Europe: Economy, Business and Management, 2(19), 21-26. (in Ukrainian)

6. Kolektyvni zasoby rozmishhuvannja (2011-2020) Derzhavna sluzhba statystyky Ukrajiny. Available at: http://www.ukrstat.gov.ua/ (in Ukrainian)

7. The Cabinet of Ministers of Ukraine (2017) "On approval of the Strategy for the development of tourism and resorts for the period up to 2026". Available at: https://zakon.rada.gov.ua/laws/show/168-2017r 